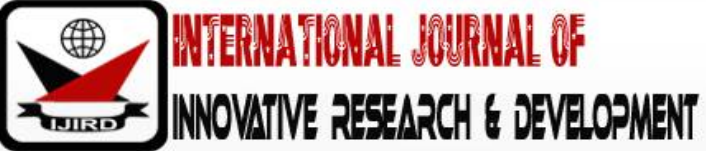

ISSN 2278 - 0211 (Online)

\section{Human Rights, National Interest and State Brutality: Lessons from Jamal Khassoggi Saga}

\author{
Dr. Joshua Igonoh \\ Senior Lecturer, Law College, Salem University, Lokoja, Kogi State, Nigeria
}

\begin{abstract}
:
Since the emergence of States on International politics till date, National interest has been the pivot of foreign policy drive of inter-state relations, the world over. Towards this, customs of international law, including Human Rights tenets that demand that states must conform to certain laws and standard within the framework of UDHR. Quite unfortunately however, member states of the United Nations are usually faced with harrowing experience in trying to align their respective national interests with international norms where doing so could put their perceived political mandate in jeopardy. In such situations, States are reported to resort to unorthodox mode of violence and sometimes, resorting to war to protect their national interest. This paper uses the murder of Jamal Khasoggi, a Saudi citizen as case study to answer questions that arise from the fallout of conflict between national interest and human rights with posers such as: where to draw the line between human rights and national interest; who qualifies to champion international outcry against human right abuse and where to draw the line between human rights and national interest? In the end, the paper called for caution in the call for the hangman against Saudi Arabia, a country that is just emerging from the past that was blanketed in secrecy into whatever human right portends in this era.
\end{abstract}

Keywords: Rights, national interest, national values

\section{Introduction}

On October 2018, the news of mysterious disappearance of Jamal Khashoggih, a Saudi-born journalist and Human Rights activist greeted the world with shock and constertination.1 After a muted silence on the where-about of the journalist with extensive cctv recording attesting that he entered the Saudi consulate in Ankara, the Saudi government eventually gave a lame-duck explanation on how an unexplained struggle ensued between Khassoggi and some Saudi personnel shortly after he entered the consulate, which resulted in his death.2

Turkey, on whose soil this sordid operation was carried out has been vocal and active since then, at the forefront of quest to bring to justice all those connected to this senseless and unprofessional bloody murder of such international journalist that had been on the watch list of several landmark mass media outlet, the world over. This unfortunate murder of a Saudi national by the same government that was meant to protect him raises several political and Jurisprudential questions that call for resolution now that the cry for justice for the dead is at its height. Amongst such issues are, where to draw the line between human rights and national interest; who qualifies to champion international outcry against human rights abuses; and where to draw a line between national values and national interest.

\section{Legal Framew ork and Politics of Universal Human Rights}

Human rights as a concept has philosophical root in the natural law School, warranting its description by Cranktson as the "twentieth century name for what has been traditionally known as natural rights, or in a more exhilarating phrase, rights of man".3 Drawing its inspiration from nature, the theory of natural law holds that there is some connection between law and the value of freedom and equality in the sense that an oppressive and arbitrary rule overhuman beings is incompatible with human nature, as intended by the creator.4 It was on this principle that the 17th and 18thcenturyphilosophers like Hobbes, Rousseau, Montesque and Locke developed their concept of inalienability and inprescriptibility of human rights on the notion that human rights attach to all humans, everywhere, at all times, by virtue of their being human.5 Here it appears that the term "inprescriptibility" is only understood to mean rights that are not created or conferred in the strict sense of the word, but only legislatively endorsed.

The word "right" itself has been defined as that to which a person has a just and valid claim, whether it be land, a thing, or the privilege of doing something or saying something.6 Rights that are guaranteed by positive law (lexlata) are referred to as legal rights while those that are yet to receive such legal endorsement may only exist more in moral capacity.7 This is why Oputa defined the word "right" to mean, the capacity residing in one man or group to control the actions of others with the assent and assistance of the State.8 For Akande, the word "right" means "a just claim", adding that when someone is described as having a right, he is acknowledged to be entitled to something to which he has a just claim under the law.9 
Closely linked to the word "right" is the word "human" which Yerima simply defines as "pertaining to, characteristic of, or having the nature of mankind"10. From this, it is clear how human rights came to be variously defined as "the right one holds by virtue solely of being a human person... right naturally inhering in the human being"11; "those claims made by men, for themselves or on behalf of other men, supported by some theory, which concentrates on the humanity of man as a human being, a member of mankind"12; "rights and freedom which every person is entitled to enjoy possibly deriving from natural law"13; "rights one has simply because one is a human being"14; "rights which all persons everywhere and at all times equally have by virtue of being moral and rational creatures" 15 .

Ogbusummed up human rights as rights that are:

Inherent in any human being simply because of his humanity-the birthright of all mankind. The expression "human rights" in its widest connotation embraces those civil, political, economic, social, cultural, group, solidarity and developmental rights which are considered indispensable to a meaningful human existence16.

The obvious shortcoming in all these definitions is that at a glance, they give impression that all rights attaching to man as a member of mankind are enforceable in law; a summation that is impracticable because of economic and social differences of each nation state. This is why this paper would rather prefer a more embracing definition of human rights in its simplest form, as rights inhering to every member of mankind as endorsed by law. This is because in practical terms, only rights endorsed by the domestic laws of each nation state qualify as human rights, usually referred to in National Constitutions as "fundamental rights" because they are "guaranteed by basic or prominent law... tied to fundamental freedom"17.

Yerima put the distinction more succinctly when he said human rights arising from natural rights predate the States; they are not given by positive law nor capable of being abrogated, while fundamental human rights are guaranteed by National Constitution18. What is apparent from all these in the Nigerian scenario is that some "human rights" are entrenched in the Nigerian Constitution not in the sense that they are conferred or prescribed by the Constitution but only guaranteed by the Constitution and therefore regarded as "fundamental human rights"19. These are rights which the Supreme Court said are not just rights, belonging to the citizens but rights that have always existed even before orderliness prescribed rules for the manner they are to be sought20. No wonder, Cicero said "It is a sin to try to alter this law, nor is it allowable to attempt to repeal any part of it and it is impossible to abolish it entirely"21. The ugly consequence of man's inhumanity to man arising from the way the Second World War was prosecuted definitely played into the long standing philosophical principle of human rights as a nature-endowed, imprescriptible and indivisible right.22 The atrocities of Nazi Germany and the beastly horror of the regime during the war directed attention to the nexus between outrageous behavior of a government towards its own citizens and aggression against other nations of the world.23 It brought to the fore the need for effective protection of human rights as an essential condition for international peace and progress, stressing that as long as human rights are respected, democracy is secured and danger of dictatorship and war is remote.24 It was in pursuit of this that the UN Charter imposed obligations on member States to universally guarantee and encourage the protection of human rights in fulfillment of the ideal for which the Allied Powers went to war.25 That was why the UN Charter took a stride in reaffirming faith in fundamental human rights, in the dignity and worth of the human person; in the equality of rights of men and women and the nations, large or small, as part of the measure for promoting human rights for all, without distinction as to race, sex, language or religion.26

In further pursuit of human rights universalization, the Charter also mandated the UN General Assembly to "initiate studies and make recommendations for the purpose of ... assisting in the realization of human rights and fundamental freedoms".27 The essence of this was to ensure universal "respect for human rights and for fundamental freedom for all, without distinction as to race, sex, language or Religion".28

The declaration was not a binding legal instrument but as general principles of law or standard by which State acts and policies could be measured. It did not purport to be a binding instrument but a "path-finding instrument" by which to measure the degree of respect for, and compliance with international human rights standard; as the bastion of human rights security and defense in a world that was already bedeviled by all kinds of abuses.29 That was why Elias referred to it as "the most important document to has emerged from the UN organization as the foundation of its existence... the nucleus of an organism which is in the process of rapid growth to great dimensions by its own inner dynamism".30 He called it "the seed of the idea of human rights, as one of the cornerstones upon which the post 1945 World War should be built". For Ogbu, the Declaration was "an authoritative definition of human rights, setting out the principles and norms of securing respect for the right of man everywhere in the world".31 This declaration no doubt ushered in a new era of human rights with multilateral approval, resulting in internationalized form of legitimacy as it created what was then described as a universal standard, external to individual States by which State laws, policies and values could be evaluated.32

It would be recalled that all along, protection of State sovereignty and non-interference in the internal affairs of each State was the dominant philosophy of international law. Therefore, the elaborate provisions of the Charter tending towards universalization of human rights was seen as an effort towards dislodging this statusquo because the world was still riddled with diverse political and economic ideologies based on religion, culture, race barriers and the regime of several dictators, who believed that universalization of human rights could whittle down State autonomy.33

Thus, when the UN Charter braced through the stormy opposition of the dissenting voices and in its preamble and several provisions, it made ample provisions that tended to show that the sovereign-exclusivity of various States and regime was going to be subjected to international scrutiny by these provisions, the organization had set a scene of under-current politics that must check-mate further erosion of the principles of State sovereignty.34 The battle-line was redrawn when the Economic and Social Council35 established a Commission on Human Rights to draft an International Bill of Rights.36 
Opposition at that level seemed to be championed by the Soviet Union with the followership of a few others at the vote on the Charter.37

Top in the controversies bedeviling birth of the Bill of Rights were the ideological and political differences, the quest to protect State sovereignty and the right to property which dogged the heels of the Declaration earlier.38 The aggressive opposition mounted by the Soviet Union on communist ideological stance and Saudi-Arabia on Islamic principles particularly stood out, leading to the delay in resolving the riddle for about eighteen years.39 As Gasiokwu observed, "ideological differences between socialism and capitalism influenced the debates and that was how the Soviet Union introduced "controversy about the rights to property ...in the original Universal Declaration (that) led to its being left out of the Covenant"40Such influence no doubt, arose from the political muscle of Soviet Union in the entire build up but what happened to the values and ideologies of "smaller nations" with little or no political clout like Soviet Union, is likely to be responsible for the clamour for relativism today. The opposition-block formed on the ideological basis of these two nations is of paramount importance to this research because of the claim of the Universal declaration to a "common standard". The Declaration was said to act: as a common standard of achievement for all peoples and all Nations, to the end that every individual and every organ of society, keeping this declaration constantly in mind, shall strive by teaching and education, to promote respect for these rights and freedoms and by progressive measures, national and international, to secure their Universal and effective recognition and observance, both among the peoples of member States themselves and among the peoples of territories under their jurisdiction.41

Explaining the purport of this provision, Ndubisi and Nathaniel said "the link between human rights principles and human nature makes them universal" noting that these principles are the same everywhere, irrespective of sex, race or creed".42 But the question that begs for response is: on whose standard was the universalism of human rights determined, in the Universal Declaration of Human Rights? It is remarkable to note that as at 1945 when the United Nations was founded and even as at 1948 when the Human Rights Declaration was adopted, most of Asia and Africa were still under western colonial rule and it was their independence in the 1960s that doubled the United Nations membership in the mid-sixties. Indeed, the situation of Islamic countries was not any different because as at 1948, only five out of twenty-two full members of the Arab States that now form the Arab league existed.43 From within today's forty-five members of Organization of Islamic Co-operations (OIC), only seven existed, Turkey and Iran inclusive.44 Even then, the debate amongst the existing Arab Nations on the propriety or otherwise of adopting and approving the UDHR on the basis of Islamic Ideology availed nothing because at the vote, only Saudi-Arabia abstained.45

While Arab nations that existed at the time may be adjudged culpable, can that be said of the nations that never existed at the time or is it also about the argument that the emerging nations were part and parcel of those that glossed over their rights to protest?.46 Be that as it may, it must not be forgotten that human rights have evolved beyond their original realm of equality to specific protection, covering almost every aspect of human life.47Therefore, nations ought not to be held to ransom over what was done when they did not exist as a nation or when they lacked capacity to oppose ideologies of their economic or political benefactors. This is the perspective from which this research is identifying with the plight of some of the nations, including Nigeria that now press for relativism even when they are said to have endorsed the ICCPR, the ICESCR and their protocols as economic surrogates to their international donors.

The Arab nations have particularly advanced their quest for relativism to the United Nations and have continued to canvass for it till date. Shortly before the World Conference on Human Rights in Vienna in 1993 for example, the Organization of Islamic Conference (OIC) initiated "the Cairo Declaration on Human Rights in Islam" which was presented to the then Secretary General of the UN, Kofi Anan with strong pressure from Iran, Saudi Arabia and Iraq for the UN Commission on Human Rights to accept the Cairo Declaration as an alternative for Muslim Countries.48 Although this measure has not yielded any positive result, it speaks volumes of the extent of disenchantment with the present status of Universality of human rights to thus call for a review.

For African nations, they rather resorted to floating what looks like a more indigenous human rights charter to compliment the Universal Declaration of Human Rights. A close look at the said Charter suggests that it is Africa's subtle way of fighting for relativism because it seeks to fill gap of cultural values that did not attract any serious attention in the International Rights Covenant.49Tibi seems to grasp the basis of nations resisting the present status of Universalism when he said the issue of relativism is all about differences in "ethical traditions, culture or religion" which he said had "impact on human rights, both in theory and practice".50 As the learned author observed, "Islamic and Western Worldview are not only different but also raise different claims, the politicization of which could lead to a conflict that could result in a clash of civilizations".51 This, in the view of this research is the only way failure of Arab Spring can be explained, where attempt to orchestrate displacement of the more settled religious democracy or oligarchies for western form of democracy has created unimaginable crisis in several Arab nations today. 52

All the same, it appears that in spite of the differences in values, there are areas of cross-cultural universalism or overlapping consensus of all laws including human rights, which should form the thrust of universalism where all cultures have some basic moral values in common, by which some culturally sensitive rules may be formulated to pull the people together, rather than divide them. While this view represents a good measure of tolerance but the other side, which is the need to find a common ground that should warrant some harmless relativism does not seem to attract such considerable sympathy. This is why this paper canvases for relativism on religious and moral values alone because they seem to command larger followership and by implication, universal outlook than the larger tenets of cultural values especially because, values of each people are dictated by their core religious and moral beliefs. 


\section{Survival Instinct and Political Inevitability}

On the basis of the contractarian philosophy of law and governance, it is often posited that in exchange for security of life and property, the society divested itself of private rights to a sovereign, represented initially by a monarch and later, by an organized government.53 The import of this philosophy is that the people themselves conceded to a form of limitation upon absolute nature of their human rights in favour of the monarch or whoever holds the people's mandate per time, per time, to do all within its powers to ensure security and social instability as a benchmark for determining legitimacy of rulership.

Divisive as this philosophy has been amongst scholars but it is obvious that neither the naturalists, positivists, historical or sociological schools, nor the respective philosophers, including Moresque, Hobbes, Engel or Karl Max have been able to proffer a more realistic alternative. Therefore looking at it beyond its critical realities would justify this philosophy as the basis of the belief of the far right politicians and administrators that the rule of law can, under certain circumstances be subordinated to, and even superseded by broader national security considerations.54 It is remarkable to note that human rights and its Rule of Law derivatives are not absolute anywhere in the world especially where exercise of one's so called rights impugn on State functions and security.

By the trend of absolutism read into human rights and the rule of law by activists between the tail end of the 20th century into the 21st century, the world seems to forget so fast that elasticity in the import of the tenets of human rights could render the law superfluous and therefore, of little effect when seen only as a framework for protecting individual interest, giving no room to State discretion in any forum. Whether such a posture constitutes the 21st century measure towards Fredrick Engel's Markian doctrine of "withering away of the State" is difficult to fathom but the reality of political arrangement of this century seems more, to lean towards the mythical Hege lian construct where State must perpetuate itself by all possible means to maintain its supremacy in pursuit of its primary responsibility before its theoretical obliteration. 55

It is remarkable to note that human rights, no matter how they are couched remain unenforceable until they are endorsed by domestic laws of each State. The import of this is that all human rights Covenants and Convention remain inapplicable in any Member State of the United Nations until such Member State endorses them via its domestic Legal process even when some of the basic rights may constitute international customary Laws of nations.56 By implication, it means domestic laws of member States take precedence over certain human rights conventions until they are duly ratified. This is where the issue of National interest may over ride human rights principles, especially where a particular Member State declines to endorse its application.

Placing National interest above natural or human rights is not a new phenomenon; it is only where to draw the line between the two that has posed the greatest riddle to the concept of human rights over the years. Indeed, in modern times, National interest has become the pivot and launch-pad of foreign policy of most States thus bringing human rights and fundamental rights on coalition course with the issue of political, security, economic and social considerations of States.57 This is because, no matter the commitment to world peace, it is politically understandable that every responsible government must first and foremost seek interest of the people that constitute its primary constituency.

This has been evident in the foreign polices of Britain, the United States of America, Russia, China, Iran and other world powers, including the third world countries whose foreign policies are usually grossly dominated by neocolonialist considerations.58 Thus, in the US, from President Woodrow Wilson's "Monroe Doctrine" forbidding European involvement in North and South America, to President Nixon's "Nixon Doctrine" at "Vietnamizing" the Vietnam war, it has been obvious that US foreign policies have always been fashioned to reflect domestic policy of presenting the United States of America as the most powerful, secure and prosperous Nation.59 That was why despite breach of the "red line" rhetorics of Obama administration on the use of chemical weapon in Syria, the administration loathed full scale involvement in the Syrian war because a large scale involvement would not save National interest of the United States. As President Obama put it "my only interest is to end suffering and to keep the America safe": although he was practically unwilling to take steps that would "end suffering" as professed.60

This is the angle from which we all must learn from the Khasoggi murder, both from the perspective of Saudi Arabia and President Donald Trump's cautious approach to the ugly situation. To be fair to Donald, he has condemned JarmalKhassoggi's murder in all unreserved terms but with all the domestic challenges to his administration, it is obvious that he needs to pitch his tent in the National economy which is his strongest point. He needs to convince the American electorate that his detractors may wield the axe of indictments against him in the name of Russian collusion in the 2016 Presidential election; and those opposed to his candidature from the onset may weep up sentiments against all the import of his: "America first" policy but taking America from the recession into which Bush and Obama administrations dragged the nation is a non-negotiable task that would give his first tenure the nod that could earn him another tenure.

In the overall circumstances of Khassoggi's death, it is obvious that Saudi Arabia and probably the Crown Prince were to blame, but the primary question Is, which interest takes precedence as between American National interest and the need to "punish" Saudi Arabia by terminating existing trade deals? In determining where to take bearing from, it must not be quickly forgotten that although Khassoggi was said to be on self-exile in America but the atrocious act was not carried out on American soil. It is therefore fool-hardy as some American Senators insist that some major economic fall-outs must be ensured to send the right signal to Saudi Arabia that America would not condone any wanton breach of its values.

As a scholar put it:

A key concept of both the theory and practice of international relations is National interests. It is not values, virtues and brotherhood.... that shape relations between nations. It is the interest of a group of people that determine the nature of relations between and among collective units of human beings. Nations do seek to secure their own interest in 
their dealings with other Nations.... What counts as national interest cannot always be explained solely on items of coldblooded real-policies; many other factors shape it61

As a matter of social reality, natural instinct for both individual and human beings remain the collective assemblage of National quest for security which Nations could pursue at all cost. Here, values and principles are only regarded as key components of State notion of National Interest, balancing peace and harmony internally and externally as the bench mark.

In all of President Trump's condemnation of Khasoggi's murder, he has been quick to observe that breaking ties with Saudi Arabia over this ugly incident would leave America worse for it as Russia and China would easily fill- in the gap. With this also is the strategic place of Saudi Arabia in America's fight against terrorism; the prosecution of the war in Syria where Russia and Iran, two major antagonists of America are main actors, and the need to find a lasting solution to the Israeli-Palestinian conflict, all of which have been central to American foreign policies over the years. In our view, all of these must be Trump's way of emphasizing the need to "recognize the importance of power equilibrium on regional and global levels" as would properly define the world is notion of national interest that could fortify strategies of nations who take pleasure in exporting instability to other nations.

From the guarded pressure of President Edoghan of Turkey on this issue, it is obvious that even when he seeks to present himself as a protector of human rights but he has been careful not to malign the Saudi monarch or even mention the Saudi Crown Prince directly, so he could secure Turkish economic interest with the Gulf States. As a matter of fact, it is obvious that Turkey's apparent tough stance has been geared towards attracting international spotlight after her oppressive outing against all imagined opposition in the name of counter tourism following the failed coup in 2014. But the world must not allow itself to be fooled by President Edoghan who has the blood of several people including Journalists on his hands, while having several of them behind bars without proper charges.

In as much as we do not justify the dastardly act of Saudi Arabia in the Khassoggi saga but it would be counterproductive if the world submits to Turkish pressure, which is on vendetta mission for Saudi alienation of Quartta, an ally of Turkey. Should America take the pretensions step that the democrats and some disgruntled politician are advocating, she would be worse off the murder off Khassoggi because it would by such error fall before competing world powers like Russia and China who would leave no stone unturned to see America on its knees this is why we counsel that should America fall at all, it must not be in sympathy with what happened in turkey. Instead America must take clue from attitude of European Union countries maintaining distant stance on the matter in their individual and collective interest.

\section{Human Rights and National Interests}

Whether from the perspective of natural law or the positivists, the world must see the need to always balance the conflicting understanding of those two philosophies on the concept of human rights, to meet the realities of recent evolution of human rights, alongside the need to secure State interest. This is because, human rights, on whatever premise cannot make sense outside the framework of peace and harmony in the society. This must be done not only on the understanding that human rights is not absolute anywhere but also, that there won't be any Nation in the first place, where order, security and stability are challenged by individual rights.

As we earlier mentioned, all nations seek security for themselves as natural instinct for both individual human rights and their collective body as a State. For this reason, Nations are known to go to war when they have reason to believe that their interests are threatened and for this, they kill when they think it is the only way they could eliminate threat.62 Critics of this stance should examine details of what happens behind the façade in national emergencies of various Nations with America, Russia and China as case study.

When Sweden, United Kingdom and America demanded the head of Julian Assange on various charges some seven years ago, Eckwandor protected him in her embassy in London on human rights ground. But when Eckandors national interest came of line, that little nation wasted no time in beating human rights to the background and handing over Assange to the metropolitan police on trump-up reason they could have easily contained.63 This is the perspective from which international community must approach the flaw of Saudi Government in the in the handling of khassoggi scandal. No matter how must that Islamic nation yields to international overtures for human rights leverage, but the world and even her own zealot- citizens must not over drive human rights wagon, over right to over-run the ideals upon which Sandi Arabia nations has survived over the years. To do so is to destroy one nation that that has a rallying point to almost all nations of the world on the whims of principles of human rights, with all its unwieldy boundaries.

In the face of the world pressure for the hangman against Saudi Arabia on the murder of Khassoggi, we all seem to be oblivious of the totalitarian background of Islamic rule where Saudi Arabia is coming from, to the new experience of political external policies of the Kingdom previously dictated by absolute secrecy and state sovereignty alone, the world hardly enjoyed the privilege of prying into her human rights performance. And now that the kingdom seems to be opening the lead and allowing some form of dissention, the world is in a hury to judge errors of the kingdom by the standard of nations that have several centuries or at least decades of human rights pursuit to their credit which attitude may be counter-productive in several ways.

Firstly, it raises unguarded dissidents like Khassoggi seeking world attention, even if at the expense of security of their mother land without a second thought on the reality that to a large extent, quality of human rights in the mere developed democracies did not get to the present state in just a decade. Such unschooled pursuit of human rights, including the tenets of democracy has been the mother of Arab spring since 2011 and even the unmanageable political crisis in Iraq, Afghanistan, Syria, Yemen, and Libya till date. 
Beyond this is the fact that the present level of pressure could drive other undemocratic nations back into their cocoon, for some reprieve, no matter how short lived. Such development does not do human rights evolution any better and must therefore be checked.

As a scholar put it, Narrowing down of the scope of action available to the state, and circum scribing it by imposing limitations ostensibly issuing from argument predicated on the rule of law and observance of human rights would not be of much help in urging action towards addressing (certain) necessities.64

Instead, under, certain extreme considerations and momentous difficulties, States may be obligated to dispense with some expedients of narrative standard and adopt practical but painful measures that could sometimes contradict the rule of law or even the dictates of morality. Such aberration forced upon the State to protect itself and its citizens against egregious threats and distractions undermining the commonwealth of each State must be sympathetically approached by international community even if dispassionately because there can be no community without due order, overseen by State apparatus.

This is because, the pace and tempo with which the law responds to the need for action in addressing some issues of national security and the bottlenecks created by International Conventions acting as cover for dissents could be frustrating sometimes so that where government measures the risk of inactions against employment of unorthodox measures, it may resort to the later at the risk of international condemnations as has become the situation of the Khassoggi case.

Obviously, Saudi Arabia is not the first to take such risk. It is only a matter of the political clout of the culprit or the power to which it is connected. It is on record that the U.S has not yet severed relationship with Turkey, whose foreign policy centers on wiping out every perceived opposition; it is on record that the U.S still courts Russian despite trailing and killing those opposed to Russia ideals in foreign countries; we have not forgotten too soon the impunity with which Myanmar and Egypt have trampled underfoot the human rights of perceived opposition till date; we are not oblivious of how desperately the U.S has been working towards bilateral talks with North Korea despite the high-handedness of that government on perceived dissidents. Indeed, the brutality with which Russia prosecuted its support for Assad in the Syrian war over the years, despite artery at the United Nations Security Council points to the fact that the United Nations is only a club of convenience ruled by interests of major world powers. With some understanding, it is obvious that whether state power is condemnable or not is determined by which power broker a nation pitches her tent with. That explains recent shifts in political policies of several countries of the Americas and Arab nations to Russia because the way the Syria war has played out convinces every toddler politician that the more brutal your international mentor, the safer.

\section{Summary, Conclusion \& Recommendations}

This paper has shown that universal as the legal framework of human rights may claim to be but it is obvious from the events leading to the universal Declaration of Human Rights and all its Conventions and Protocols that as long as the system tries to play down on State for private interest, the gap between national values of State membership and Human Rights ideals will continue to widen, thus hampering the original dreams of the founding fathers of Human Rights ideology. For this reason, it is recommended that individuals and States alike must be less inward looking in seeking their interest if the world must not return to the pre- Second World War era. Regarding Saudi Arabia in its present ugly outing from the back-drop of Khassoggi murder, various States must wake up to the reality that today's world has moved from the past where State sovereignty dominated International politics. All the same, the world must be more sympathetic in dealing with human right complaints against States with long standing undemocratic history which decide to thread the path of honour in trying their hands-on democratic principles so that the system may not be grounded for the reason of isolated cases of human rights flaws. Whether as journalist, politician, human right activists or dissidents, we must not forget to place State interest above our personal interest or else, we could destroy the very system that hosts the interest we seek to protect, after all.

\section{References}

i. Cranskton, N., 'What are Human Rights?' <www1.umn.edu/ humanrts/ ../ what-are-human-rights $>a c c e s s e d$ on 1006-2016. See also Ogbu, O.N., Human Rights Law and Practice in Nigeria (Enugu: CIDJAP Press, 1999) 3. See also Nwabueze, B.O.,Constitutionalism in the Emergent States (London:C. Hurst and Co.ltd; 1973) 41; Roscoe, P.,'Philosophical Foundation of Human Rights' (UNESCO, 1986); Karel, V., International Dimensions of Human Rights (Paris: Pendone, 1981)

ii. Ogbuop.cit.

iii. Hobbes, T., 'History of the Inalienability Rights Argument' $<$ www.abolish-human-rentals.org/ hobbes $>$ accessed on 10-06-2016; Rousseau, J., 'The Inalienable Rights of the Individual and the Sovereign Will' <quadrant4.org/rousseau.html> accessed on 10-06-2016; Montesquieu, W.C., 'Inalienable Rights'<www.ellerman.org/ inalienable-rights/ > accessed on 10-06-2016; Locke, J., 'Theory of Inalienable Rights' <communityweber.edu/.../ theory-of-inalienable-rights>accessed on 10-06-2016

iv. Ibid

v. Ibid at 2

vi. Oputa, C., Human Rights in the Political and Legal Culture of Nigeria (Lagos: Nigerian Law Publications Ltd; 1988) 38-39

vii. Akande. J., 'Securing Individual Rights' Being part of the proceedings of the conference on Constitution and Federalism held at Unilag, Nigeria; 23-25 April, 1996 
viii. Yerima, T., 'Appraising the Significance of the Liberal and Utilitarian Conceptions of Human Rights in the 1999 Constitution of Nigeria' Ikeja Bar Review, [2007] vol. 2, Part 1. See also Hornby, A.S., Oxford Advanced Learners Dictionary (Oxford: Oxford University Press, 1998) 581.

ix. Rutherford, L, and Bone,S., (eds) Osborne Concise Law Dictionary, 8thedn (London: Sweet and Maxwell, 1993) 293

x. Donnelly, J., 'Human Rights and Human Dignity: An Analytic Critique of Non-Western Conceptions of Human Rights'. American Political Science Review. [1982] vol.76. 305

xi. Ibid.

xii. Nwabueze, B., Constitutionalism in the Emergent States (London: C, Hurst \&Co; 1973) p.83 See also Ogbu, op.cit

xiii. Nwabueze,op.cit

xiv. Ogbu, op.cit

xv. Ibid

xvi. Yerima, T., op.cit. This is why Constitutional Rights like those guaranteeing life, liberty and property are presented in negative terms. See Ogbuop.cit; Gasioku, op.cit.

xvii. Saude v Abdullahim (1989) 4NWLR (pt.116) 387 see also Yerima, op.cit 207; Yerima prefers to refer to the rights in chapters $2 \& 4$ as human rights but distinguishing those in cap.2 as fundamental rights.

xviii. RansomeKuti v Attorney-General of the Federation (1983) 2NWLR (pt.6) 211 at 230

xix. Ogbu op.cit at 36

xx. Oppenhiem, L., International Law: A Treaties (London: Longman Group, 1970) 737. See also Ogbu, op.cit at 35

xxi. See Preamble to the Charter. See also Ogbu, op.cit at 36

xxii. Article 1(3) of the United Nations Charter (hereinafter referred to as, UN charter)

xxiii. Ibid

xxiv. Art.13(b) and 55(c), UN Charter

xxv. Article 1(3) UN Charter,op.cit.

xxvi. Gasiokwu, M.O.U., Human Rights, History, Ideology and Law (Jos: Fab Education Books, 2003) 136

xxvii. Elias, T., New Horizons in International Lawop.cit.

xxviii. Ibid

xxix. Ogbu, op.cit., at 40-41

xxx. Brownlie, I., and Goodwin-Gill, G., Basic Documents on Human Rights, 5thedn. (Oxford: Oxford University Press, 2006) 23.

xxxi. Meyer, W., 'The International Bill: A Brief History' in Williams, P., (ed). The International Bill of Human Rights (Glen Ellen: Entwhistle Books, 1981) P.xxiii. See also Eze, op.cit at.38

xxxii. Meyer, op.cit.

xxxiii. Hereinafter referred to as ECOSOC established pursuant to Art. 7 of the UN Charter

xxxiv. The Commission established in 1946 pursuant to Art. 62 had Eleaner Roosevelt as the Chairperson with 18 members drawn from various nations. See also Meyer, op.cit

xxxv. The States were Soviet Union, Saudi Arabia, Ukraine supported by Countries like the Arpatheid South Africa,Belarus, Czechoslovakia, Poland and Yugoslvia

xxxvi. Ogbu,op.cit. at $40-41$

xxxvii. Gasiokwu, op.cit. see also Ogbu, op.cit at 42

xxxviii. Gasiokwu, op.cit

xxxix. Proclamation of the Charter. See also Gasiokwuop.cit., at135 -138

xl. Ndubuisi, F.N., and Nathaniel, O.C., Issues in Jurisprudence and Principles of Human Rights (Lagos: Dmodus Publisher, 2002) at 181

xli. See 'Membership of the United Nations' with dates of joinder «un.org/ press/ en/ .../ org1469.doc.html>accessed on 10-06-2016. See also Gasiokwuop.cit., at 134; Tabet, K., 'Arab - Islamic Development on Human Rights' Arab Law Quarterly, Kluwer Law International, Netherlands, [2001] 256

xlii. Organization of Islamic Cooperation<www.oicun.org/ 2/ 23/ > accessed on 10-06-2016. See alsoOgbuop.cit., at 42

xliii. Malin, D., 'Islam and Human Rights'<www.gupee.ub.gu.sc/ ... ./ 200484pdf>accessed on 16 - 02-2015

xliv. Existing nations were Egypt, Iraq, Lebanon, Saudi-Arabia and Syria. See Malin, Ibid, at 9-10

xlv. Tabet, K., 'Arab - Islamic Development on Human Rights' Arab Law Quarterly, Kluwer Law International, Netherlands, [2001] 256.

xlvi. Meyer, A., Islam and Human Rights - Politics and Traditions, 3rdedn (London: Westview Press, 1999) 11. See also Ogbu, op.cit., The Arab pressure has also given rise to 'Declaration on the Protection of Refugees and Displaced Persons in the Arab World, 1992' and 'The Arab Charter on Human Rights 2004'

xlvii. See Preamble to African Charter on Human and People's Rights, 1981 (hereinafter referred to as "African Charter")

xlviii. Tibi, B., Islam Between Culture and Politics (Palgrave, Palgrave Press, 2014) 214

xlix. Ibid.

1. Libya, Egypt, Syria and Yemen inclusive

li. Yerima, T; ' Appraising the significance of the liberal and utilitarian conceptions of Human Rights in the 1999 Constitution of Nigeria'Ikeja Bar Review (2007) vol.2 pt.1

lii. Gurnham, S; 'when Human Rights and National Interests collide 'sourced at www.eurekaststreet.comaccessed on 16-02-2018. 
liii. Usman, S; ' Rule of Law, Human Rights and National interest' sourced at www.dailytrust.com.ng>rule-of-law/ on 09-04-2019

liv. Section 12 (1)of the Constitution of the Federal Republic of Nigeria, 1999 like Constitutions of most countries provides that an international Treaty or convention shall not have force of Law in Nigeria without express enactment of the National Assembly.

lv. Adeyemi, J.O; 'conflict Between National interest and Human Rights: Britain's policy towards African Immigrants, 1960-2013 sourced at https:// national interest. Org/ article/ redefining the terrorist- 318 accessed on 09-042019

lvi. Ibid.

lvii. Gurnham, op.cit.

lviii. Ibid.

lix. Kalin, I; 'War, peace and National interest' sourced at ????? accessed on 05-05-2019

lx. Kalin, op. cit.

lxi. Maria - paula, R; CNN. Com accessed on 14-04-2019. See also Wikileaks; Julian Assange; Bond Villain or cyber Messiah?' sourced edition- m. Com. com/ 2019/04/12/uk/Juliam - assange - ecuad or - embassy - eviction -gb. Accessed on $14-04-2019$ 